\title{
不確かさを陽に考慮した一次元 $\mathcal{H}_{\infty}$ コントローラ による速度制御系のロバスト制振制御
}

$\begin{array}{llllll}\text { 学生員 } & \text { 橋 } & \text { 本 } & \text { 誠 } & \text { 司 } & \text { (宇都宮大学) } \\ \text { 正員 } & \text { 船 } & \text { 渡 } & \text { 寛 } & \text { 人 } & \text { (宇都宮大学) } \\ \text { 学生員 } & 山 & \text { 本 } & \text { 磨 } & \text { 人 } & \text { (宇都宮大学) } \\ \text { 学生員 } & \text { 原 } & & \text { 賢 } & \text { 志 } & \text { (宇都宮大学) } \\ \text { 正員 } & \text { 神 } & \text { 山 } & \text { 健 } & \text { 三 } & \text { (宇都宮大学) }\end{array}$

A First-Order $\mathcal{H}_{\infty}$ Controller for Robust Vibration Suppression Control in Speed Control Systems considering Explicit Uncertainty

Seiji Hashimoto, Student Member, Hirohito Funato, Member, Kiyohito Yamamoto, Student Member, Kenji Hara, Student Member, Kenzo Kamiyama, Member (Utsunomiya University)

This paper describes a first-order $\mathcal{H}_{\infty}$ speed controller which can well regulate load speed without torsional vibration for both speed reference and torque disturbance in a two-mass resonant system. To the strategy for reducing the order of the $\mathcal{H}_{\infty}$ controller, the authors apply the state feedback compensation to modify an original resonant plant and disregard the dynamics of the modified plant considering robust stability criterion. Thus, the resulting $\mathcal{H}_{\infty}$ controller in speed control systems can be reduced to the just first in order using the modified plant.

キーワード : 2 慣性共振系, 状態フィードバック，不確かさ， $\mathcal{H}_{\infty}$ 制御，低次元化， $\mu$ 解析

\section{1. まえがき}

近年, 速度サーボ系において軽量化や小型化の要求によ り, 電動機と負荷を接続する軸の渆性が低下し, 負荷系の 固有周波数は低下寸る傾向にある。一方，電動機駆動制御 の高性能化の要求により，駆動系は高応答化の傾向にある。 この場合には，駆動系と負荷系との間で振動モードが励起 され軸ねじり振動が生じる。さらに，速度サーボ系はトル ク外乱に対しても振動しやすくなるといった問題がある。 この共振負荷系に対し，古典制御及び現代制御理論の立 場から制振する手法が種々実用化されている(1) 〈5)。また, 振動モードをもつ共振負荷系の制振制御に $\mathcal{H}_{\infty}$ 制御を適用 する場合には， $\mathcal{H}_{\infty}$ コントローラは一般に制御対象の共振 特性と極需相殺するような零点や極を持つことになる。そ のため目標値応答は制振可能であるが, トルク外乱応答に ついては共振特性が相殺されず振動抑制ができない。また, 極零相殺を用いない手法でも，目標值応答とトルク外乱応 答との間でトレードオフが必要となり，この場合重み関数 の決定に経験が必要となる。これらの課題を解決する手法 として，共振比制御や外乱才ブザーバを付加してから $\mathcal{H}_{\infty}$ 制御を適用した例がある(6) (7)。しかし，どちらの手法も
制御理論の立場から見れば，トルク外乱に対し 1 型のサー ボ系を設計しているにすぎず ${ }^{(8)}$ ，トルク外乱に詨する共振 特性の大幅な改善以望めない。さらに，振動モードの無視

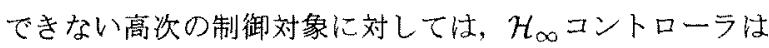
その次数が制御対象に比例し高次となる。

本諭文では，以上の課題安解決寸るために，最初に制御 対象に状態フィードバック補償安施し制御対象の極配置を 行い，特にトルク外乱の共振特性を改善する。次にここの 状態フィードバック補償された制御対象に対し，制御対象 の不確かさを陽に考慮して低次元化した $\mathcal{H}_{\infty}$ コントローラ を設計する。本提案手法では，目標值応答及でトルク外乱 応答に対持る設計指針が明確であり，従って重み関数の設 定が容易である。また， $\mathcal{H}_{\infty}$ コントローラの低次元化に上 り，その実装が実応用上容易となる。本論文では，その有 効性をシミュレーション及び実験により検証する。

\section{2．２慣性共振系の振動抑制}

本論文注，電動機上負荷がギアを介して弹性軸により接 続された共振系安制御対象と寸る。このような負荷系岋, 電 動機，負荷がそれぞれ独立した質点系を構成する2慣性共 振系となる。2慣性共振系の特徵については文献 (1)〜 (4) 


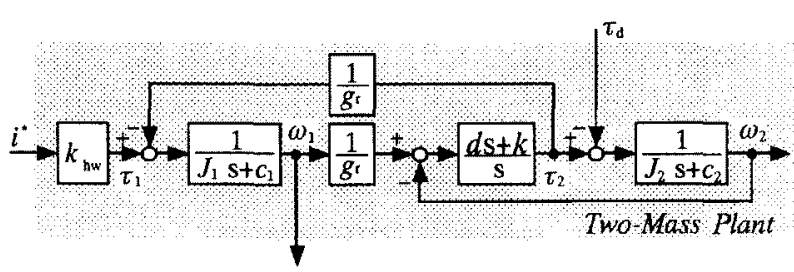

図 12 慣性共振系のブロック図

Fig. 1. Block diagram of two-mass plant.

参照されたい。

2 慣性共振系岄数式モデルとして次のように表せる。

$$
\begin{aligned}
J_{1} \ddot{\theta}_{1} & =-c_{1} \dot{\theta}_{1}-\frac{k}{g_{r}}\left(\frac{\theta_{1}}{g_{r}}-\theta_{2}\right)-\frac{d}{g_{r}}\left(\frac{\dot{\theta}_{1}}{g_{r}}-\dot{\theta}_{2}\right)+\tau_{1} \\
J_{2} \ddot{\theta}_{2} & =k\left(\frac{\theta_{1}}{g_{r}}-\theta_{2}\right)+d\left(\frac{\dot{\theta}_{1}}{g_{r}}-\dot{\theta}_{2}\right)-c_{2} \dot{\theta}_{2}-\tau_{d} \ldots \\
\tau_{1} & =k_{h w} i^{*} \ldots \ldots \ldots \ldots \ldots \ldots \ldots \ldots \ldots \ldots \ldots
\end{aligned}
$$

ただし

$$
\begin{array}{ll}
J_{1}: \text { 電動機側の慣性モーメント } & k \text { : ば好定数 } \\
J_{2} \text { : 負荷側の慣性モーント } & g_{r} \text { : ギア比 } \\
c_{1} \text { : 電動機側の粘性係数 } & d: \text { 軸粘性係数 } \\
c_{2} \text { : 負荷側の粘性係数 } & k_{h w} \text { : 変換係数 }
\end{array}
$$

この2慣性共振系のブロック線図を図 1 に示す。図 1 におい

て， $i^{*}$ は制御入力としての電流指令を表す。ここで $c_{1}=$ $c_{2}=0, g_{r}=1$ のとき $\omega_{2} / i^{*}, \omega_{2} / \tau_{d}$ はそれぞれ次式となる。

$$
\begin{aligned}
\frac{\omega_{2}}{i^{*}} & =\frac{k_{h w}}{J_{1} J_{2}} \cdot \frac{d s+k}{s\left(s^{2}+2 \zeta_{r} \omega_{r}+\omega_{r}^{2}\right)} . \\
\frac{\omega_{2}}{\tau_{d}} & =-\frac{J_{1}}{J_{1} J_{2}} \cdot \frac{s^{2}+2 \zeta_{a} \omega_{a} s+\omega_{a}^{2}}{s\left(s^{2}+2 \zeta_{r} \omega_{r}+\omega_{r}^{2}\right)} \\
\omega_{r} & =\sqrt{\frac{k}{J_{1}}+\frac{k}{J_{2}}}, \quad \zeta_{r}=\frac{d}{2 k} \omega_{r} \\
\omega_{a} & =\sqrt{\frac{k}{J_{2}}} \quad, \quad \zeta_{a}=\frac{d}{2 k} \omega_{a}
\end{aligned}
$$

ここで， $\mathcal{H}_{\infty}$ 制御による 2 慣性共振系の制振制御につい て考える。コントローラ $K(s)$ と制御対象 $P(s)$ からなる閉 ループ系のブロック線図を図 2 に示す。目標值指令 $r$ 及び外 乱 $d$ から出力 $y$ 及び偏差 $e$ までの伝達関数は, 伝達関数行列 を用いて次式となる。

$$
\begin{gathered}
{\left[\begin{array}{l}
y \\
e
\end{array}\right]=\frac{1}{D(s)}\left[\begin{array}{cc}
P(s) K(s) & -P(s) \\
1 & P(s)
\end{array}\right]\left[\begin{array}{l}
r \\
d
\end{array}\right]} \\
\text { ただし, } D(s)=1+P(s) K(s)
\end{gathered}
$$

ここで，制御対象が共振負荷系の場合， $P(s)$ の 中には 振動モードが存在する。また，一般に $\mathcal{H}_{\infty}$ コントローラ 峙制御対象の安定平面( $\mathrm{s}$ 平面)での逆システムを含む $\left(K(s)=K_{1}(s) P^{-1}(s)\right)_{0}$ 従って, (6) 式から目標值応答 $y / r=P(s) K(s) / D(s)$ に扔いて蚁 $P(s)$ と $K(s)$ で振動飞 一ドが極零相殺し $K_{1}(s) /\left(1+K_{1}(s)\right)$ となり，振動抑制が 可能となる。しかし, 外乱応答 $y / d=-P(s) / D(s)$ に対し

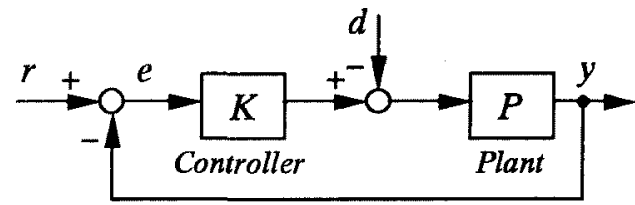

図 2 閉ループ系のブロック線図

Fig. 2. Block diagram of closed-loop system.

ては $P(s)$ の振動モードが保存され, $P(s) /\left(1+K_{1}(s)\right)$ と なるため振動抑制はできない。以上は，共振系の制振制御全 般についていえ，目標值応答と外乱応答の間では振動㧕制 という点においてトレードオフが必要であり，更なる制振 効果を得ようとした場合には何らかの補償が必要となる(9)。

\section{3. 提案する速度制御系設計法}

〈3・1） 状態フィードバック補情本論女ではトルク外 乱特性を大幅に改善することを目的に，マイナー制御ルー プとしで状態フィードバック補償を行う。すなわち， $P(s)$ が持つ振動特性の改善を行う。ここでは, (4) 式の分母多項

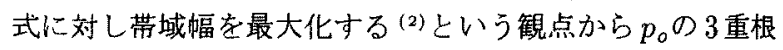
に設定し

$$
G_{s}(s)=\frac{k_{h w}}{J_{1} J_{2}} \cdot \frac{d s+k}{\left(s+p_{o}\right)^{3}}
$$

フィードバック補償による極配置の方法については省略す る。以下に極配置を決定するための手順を示す。はじめに, トルク外乱特性を改善することを第一の目的と考えて,

（1）トルク外乱から負荷速度までの伝達関数に不安定 雾点を持たないようにする。

次に, 速度コントローラの低次元化を考え(次章参照),

（2）極配置した制御対象を次数 1 の制御対象に低次元 化したときの不確かさ (乗法的)が，速度のカットオ フ周波数に影響しないように極配置を設定する。 最後に, 状態フィードバック補償された制御系の相補感度 関数は, 高周波域で-20[dB/dec]のロールオフとなり ${ }^{(10)}$, 高周波域に大きな不確かさを含む場合には, 状態フィード バックにより不安定になる可能性がある。従って，

（3）高周波域での不確かさを配㫂しできるだけ極の大 きさを小さくする。

以上が極配置の指針である。すなわち，条件 (1), (2)及び 条件 (3)の間でトレードオフが生じ, 極配置を重根とした 場合には，ほぼ一意的に極の配置を決定することができる。

この状態フィードバック補償においては, すべての状態 量が検出可能でなければならない。実際にはそのような場 合は少なく, 本論文でも電動機速度のみ検出可能であると 仮定する。従って,ここで山制御入力である電流指令 $i^{*}$ と 検出出力である電動機速度 $\omega_{1}$ から同一次元オブザーバを楼 成し, 状態量である電動機速度 $\omega_{1}$, 電動機-負荷間軸トルク $\tau_{2}$, 負荷速度 $\omega_{2}$ を推定する。また, ここではステップ状のト 


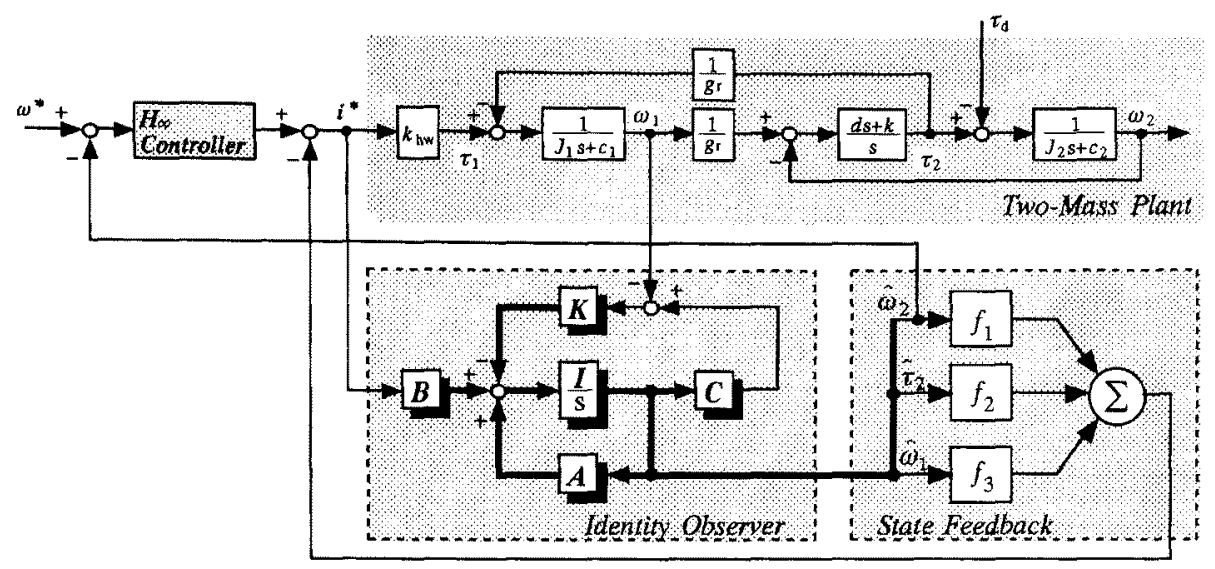

図 3 提案する2慣性速度制御系

Fig. 3. Proposed control system for two-mass plant.

ルク外乱に対してもオブザーバによる推定值が各状態量に 高速に追従するように，トルク外乱 $\tau_{d}$ も状態量しする(11)。

〈3.2〉制御対象の低次元化 前述したこおり， $\mathcal{H}_{\infty}$ コ ントローラの次数は制御対象の次数に比例して高次になる という特徴がある。しかしながら、故制においては次 式のように制御対象の不確かさ（乘法的） $\Delta_{m}$ を重み関数 $W_{T}$ で抑えることにより，その乗法的不確かさに対する口 バスト安定性を保証できるという特徴がある。

$$
\left|\Delta_{m}(j \omega)\right| \leq\left|W_{T}(j \omega)\right|, \forall \omega
$$

従って, (7) 式の状態フィードバック補償付き制御対象のダ イナミクスを無視し，(7)式を次式のように1次のモデルに 低次元化する。

$$
G_{r}(s)=\frac{k_{h w}}{J_{1} J_{2}} \cdot \frac{k}{\left(s+p_{o}\right) p_{o}^{2}}
$$

(7) 式で分子多項式の減衰保数 $d$ は, 一般にば称定数 $k$ と比較 し十分小さいため，ここではそのダイナミクスも無視する。 ここで，ダイナミクス無視に対する乗法的不確かさ $\Delta_{m}(s)$ は次式となる。実際には $\Delta_{m}(s)$ 中には (7) 式そのものの不 確かさも含まれるが，状態フィードバック補償により，こ こで考える不確かさに対し十分小さい(12)。

$$
\Delta_{m}(s)=\frac{G_{s}(s)-G_{r}(s)}{G_{r}(s)}
$$

〈3-3〉 $\mathcal{H}_{\infty}$ 速度コントローラの設計 $\quad(9)$ 式の低次元 化された状態つィードバック補償付き制御対象 $G_{r}(s)$ に対 し，速度制御用 $\mathcal{H}_{\infty}$ コントローラ省設計寸る。速度制御系 のブロック線図を図3に示す。

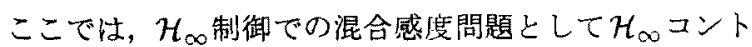
ローラを設計し, 速度制御系のカットオフ周波数の設定, 制 御系の口バスト安定化，トルク外乱に対する定常特性の改 善を行う。これらの設計仕様は，すべて重み関数に反映さ れる。本論文汒, 相補感度関数 $T(s)$ 一の重文関数 $W_{T}(s)$,
及び感度関数 $S(s)$ への重み関数 $W_{S}(s)$ を以下の 4 つの仕 様を満たすよう設定する。

（1）乗法的不確かさ $\Delta_{m}(s)$ に対し制御系をロバスト安 定とする。

(2) 速度制御系のカットオフ周波数心指定する。

(3) 制御偏差学小さくする。

(4) $\mathcal{H}_{\infty}$ コントローラの次数をできるだけ低くする。 まず，混合感度問題に打ける次式の条件から，

$$
|T(j \omega)|<\left|W_{T}^{-1}(j \omega)\right|, \forall \omega
$$

仕様 (2) を満たすためにはボード線図上での重み関数 $W_{T}(s)$ のゼロクロス周波数圣的 $[\mathrm{rad} / \mathrm{sec}]$ にすればよい。しかし， 仕様 (1)を満たすために住 $(8)$ 式の条件より $W_{T}(s)$ の大き さは全ての周波数において(10)式で示される乘法的不確か さ $\Delta_{m}(s)$ より大きくなければならない。徉って,この2つ の条件を満たすように重み関数 $W_{T}(s)$ を次式に設定する。

$$
W_{T}(s)=\frac{s /\left(0.1 \omega_{c}\right)+1}{10}
$$

ここで $(1$ 次 $) /(0$ 次 $) て ゙ あ る の は ， \mathcal{H}_{\infty}$ 制御問題での $P(\infty)$ $W_{T}(\infty) \neq 0$ 上いう条件からである。

次に重み関数 $W_{S}(s)$ を設定する。 $W_{S}(s)$ に関しては

$$
|S(j \omega)|<\left|W_{S}^{-1}(j \omega)\right|, \forall \omega
$$

という条件があり，またそのダイナミクスがコントローラ のダイナミクスに反映されるため，仕様 (3)と (4)より積分 特性に近い 1 次の伝達関数とする。

$$
W_{S}(s)=\frac{\rho}{s+10^{-4}}
$$

重み関数 $W_{S}(s)$ にはパラメータ $\rho>0$ を含ませこれを大 きく寸ることでできるだけ低感度化をはかる。

\section{4. 提案手法の適用例及びその制振特性}

$\langle 4 \cdot 1\rangle$ 速度制御系の設計 以上で提案した低次元 $\mathcal{H}_{\infty}$ コントローラによる2慣性共振系の制振制御法を，実際の 
表 12 慣性共振系の各パラメータ

Table 1. Parameters of two-mass plant.

\begin{tabular}{l|l|ll}
\hline$g_{\mathrm{r}}$ & gear ratio & 4 & \\
\hline$k_{\mathrm{hw}}$ & transfer coefficient & 4.9 & {$[\mathrm{Nm} / \mathrm{rad}]$} \\
\hline$k$ & shaft stiffness & 10.0 & {$[\mathrm{Nm} / \mathrm{rad}]$} \\
\hline$d$ & damping coefficient & 0.02 & {$[\mathrm{Nm} / \mathrm{rad} / \mathrm{s}]$} \\
\hline$J_{1}$ & motor inertia & $6.55 \times 10^{-4}$ & {$\left[\mathrm{~kg}-\mathrm{m}^{2}\right]$} \\
\hline$J_{2}$ & load inertia & $1.29 \times 10^{-2}$ & {$\left[\mathrm{~kg}-\mathrm{m}^{2}\right]$} \\
\hline$c_{1}$ & coefficient of motor viscosity & $8.09 \times 10^{-4}$ & {$[\mathrm{Nm} / \mathrm{rad} / \mathrm{s}]$} \\
\hline$c_{2}$ & coefficient of load viscosity & $1.65 \times 10^{-2}$ & {$[\mathrm{Nm} / \mathrm{rad} / \mathrm{s}]$} \\
\hline
\end{tabular}

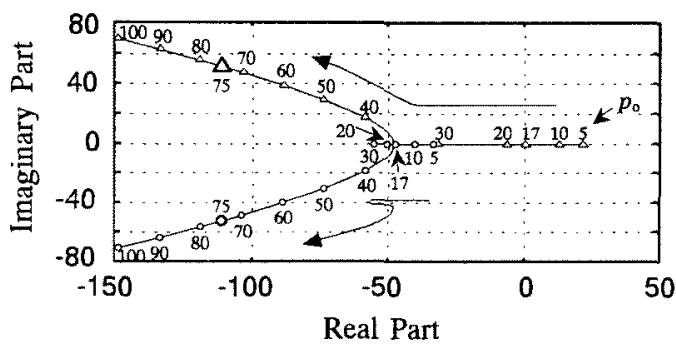

図 4 極配置に対する需点の軌跡

Fig. 4. Locus of zero for pole assignment.

適用例により示す。2慣性共振系の各バラメータを表1に示 す。前章の設計手順に従い, ここで浪速度のカットオフ周 波数 $\omega_{c}$ 在 $10[\mathrm{rad} / \mathrm{sec}]$ 上すると, $W_{T}(\mathrm{~s})$ 屾 $(12)$ 式より

$$
W_{T}(s)=\frac{s+1}{10}
$$

次に，3.1節での条件 (1) より極配置 $p_{o}$ を5から 100 一と変 化させたときの $\omega_{2} / \tau_{d}$ に対する雾点の軌跡を图 4に示す。同 図より極配置を大きくしていき， $p_{o}=17$ 以上で不安定零 点がなくなる。従って, $p_{0}=17$ の 3 重根以上で条件 (1)を 満たすことがわかる。また，(10)式よりp。を10から100へ と変化させたときの $W_{T}(s)$ に対する $\Delta_{m}(s)$ 在图5に示す。 さらに, 状態つイードバック補償無しでの 2 慣性共振系の 制御対象 (4)式のダイナミクスのうち，振動モードを表す 2 次多項式のダイナミクス在無視し

$$
\operatorname{Pr}(s)=1.4554 \times 10^{5} \cdot \frac{10}{(s+1.26) 41.6^{2}}
$$

とした場合の乗法的捸動 $\Delta_{m p}(s)$ も破線で同図に示す。図 5 より, 状態フィードバック補償した後でそのダイナミタスを 無視した方が，速度制御系のカットオフ周波数 $(10[\mathrm{rad} / \mathrm{sec}])$ に対する不確かさの影響が小さく，重みにより容易に口バ スト安定化が可能であることがわかる。また，極配置法に おいては約 $p_{o}=20$ で不確かさ $\Delta_{m}(s)$ が $W_{T}(s)$ に接し安 定限界となり， $p_{o}$ がそれ以上であれば安定化可能で，かつ p が大きいほど速度制御系の過渡特性が良くなることが予

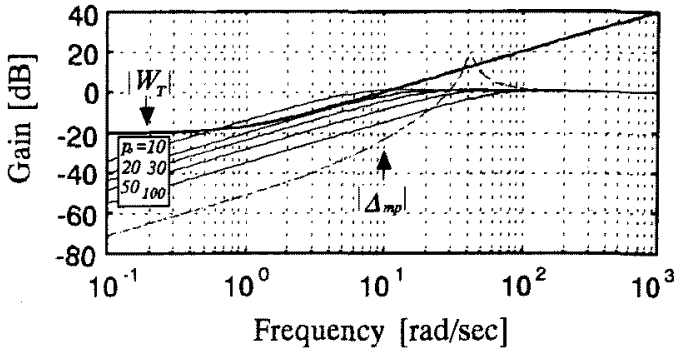

図5 重み関数と乘法的不確かさのボード線図

Fig. 5. Gain diagrams of weighting function $W_{T}(s)$ and multiplicative uncertainty $\Delta_{m}(s)$.

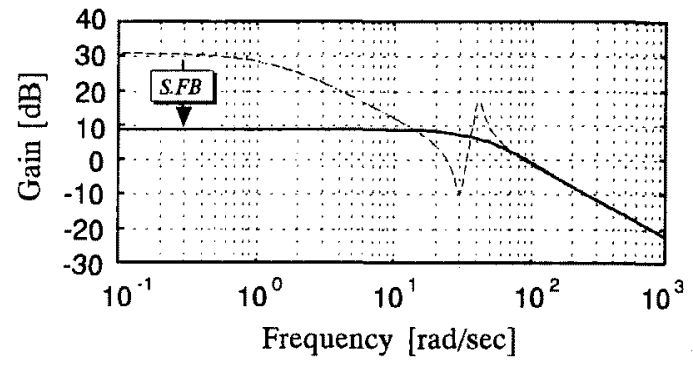

図6トルク外乱特性の改善

Fig. 6. Gain diagrams from $\tau_{d}$ to $\omega_{2}$.

想できる。以上より，ここでは $p_{0}=75 の 3$ 重根とすると (9)式から制御対象のモデルは次式となる。

$$
G_{r}(s)=1.4554 \times 10^{5} \cdot \frac{10}{(s+75) 75^{2}}
$$

状態フィードバック補償付き 2 慣性共振系のトルク外乱特 性 $\left(\omega_{2} / \tau_{d}\right)$ を図6に示す。図6より状態フィードバック補償 により共振特性と定常特性が改善されていることがわかる。

なお，オブザーバの極の設計については，特にノイズや 高次の振動モードの影響をうけないように，また，実際の 状態量をフィードバックした場合と比較しその特性が劣化 しないよう考慮し，ここではー80の4 重根とする。

次に，(15)式の $W_{T}(s),(14)$ 式の $W_{S}(s)$ 及び(17)式の 制御対象 $G_{r}(s)$ より $\mathcal{H}_{\infty}$ コントローラを設計する。ここで は制御系設計用ツールである Matlab 学用いて $\mathcal{H}_{\infty}$ 制御問 題解法 (hinf) 計算した。感度関数 $W_{S}(s)$ に㧍けるパラ メータ $\rho$ 大きくなるほど低感度化するが, $\rho=9.94$ 以上 では設計仕様を満た寸解が存在しない。よって，ここでは $\rho=9.93$ として $\mathcal{H}_{\infty}$ コントローラ $K(s)$ を求める。

$$
K(s)=\frac{307.9(s+75)}{\left(s+10^{-4}\right)(s+7976)}
$$

これより， $\mathcal{H}_{\infty}$ コントローラには，制御対象である $G_{r}(s)$ の逆システム，すなわち零点 -75 及び重み関数 $W_{S}(s)$ の極 -10-4が含まれていることがわかる。

さらに，ここでは極一7976は速度の制御帯域に比べ非常 に大きいのでそのダイナミクスを無視し，また極-10-4も 


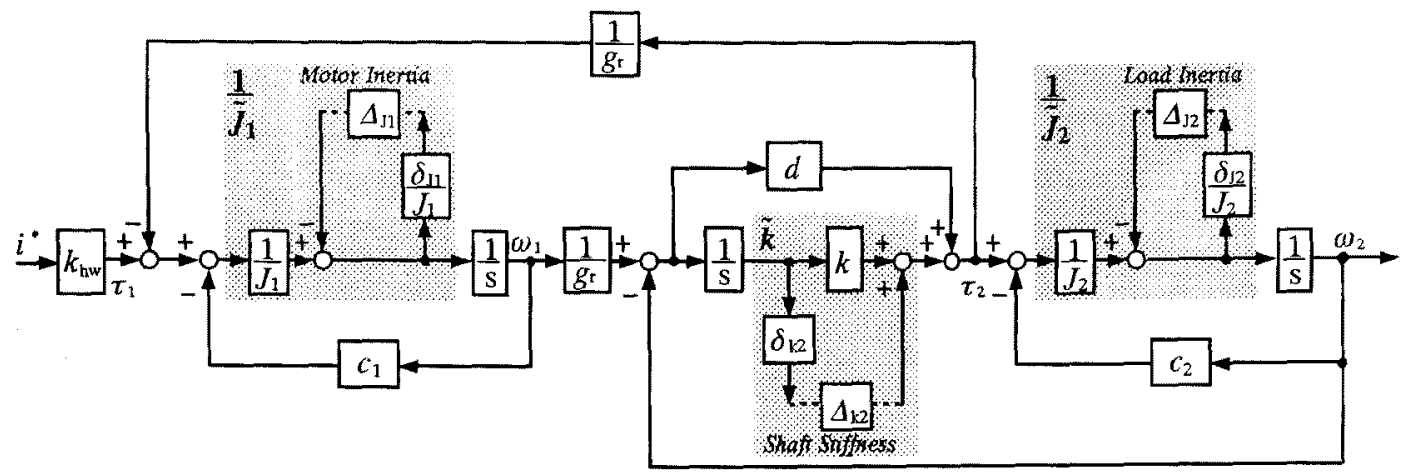

図9 $\mu$ 解析用ブロック線図

Fig. 9. Block diagram for $\mu$ analysis.

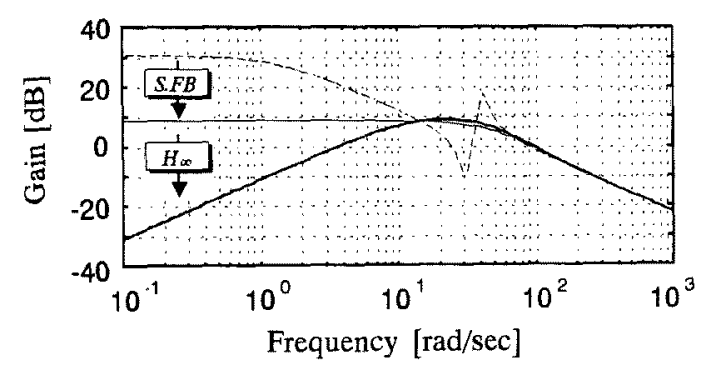

図 $7 \mathcal{H}_{\infty}$ コントローラによ合トルク外乱特性の 改善

Fig.7. Improvement of torque disturbance response using $\mathcal{H}_{\infty}$ controller.

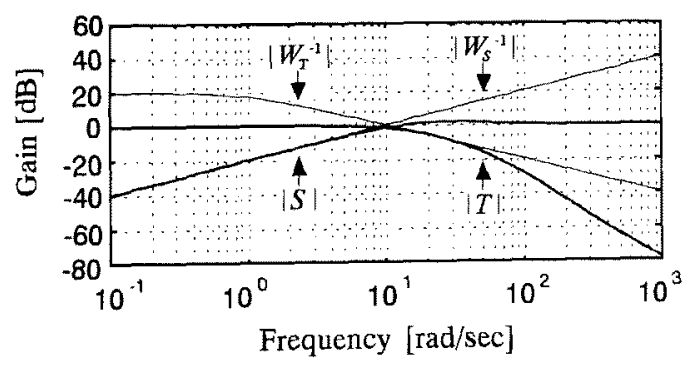

図8闒ループ系のボード線図

Fig. 8. Gain diagrams of closed-loop system.

積分器で置き換えることにより(18)式师

$$
K_{r}(s)=\frac{0.0386(s+75)}{s}
$$

この1次元 $\mathcal{H}_{\infty}$ コントローラによろ速度制御系の，トルタ 外乱に対する周波数特性を図 7 に示扵。図7から $\mathcal{H}_{\infty}$ コント ローラにより低周波領域のトルク外乱に対吉る感度特性が 改善されていることがわかる。

また，低次元化した 1 次元 $\mathcal{H}_{\infty}$ コントローラでの感度 関数 $S(s)$, 相補感度関数 $T(s)$ 及でその重み関数 $W_{S}(s)$, $W_{T}(s)$ のゲイン線図图 8 示す。图8より，低次元化し
た 1 次元 $\mathcal{H}_{\infty}$ コントローラでも混合感度問題としての条件 (11) 式及び(13)式を満たしていることがわかる。

〈4・2〉 $\omega_{c}$ の設定自由度 $\omega_{c}$ の設定自由度については， (1) $\omega_{c}$ を $10[\mathrm{rad} / \mathrm{sec}]$ 以下にする場合には，(12)式中の $\omega_{c}$ を変更し， $\mathcal{H}_{\infty}$ コントローラ安設計すればよく，(2) $\omega_{c}$ を $10[\mathrm{rad} / \mathrm{sec}]$ 以上にする場合に泫，極配置を大さくし $\Delta_{m}$ を 高域に移動させてから (1) と同じ手順を繰り返す。但し, こ の時には，DSPの演算速度及びその時可能なサンブリング 時間, また飽和により制限される。

〈4·3〉口バスト安定解析速度制御系に(19) 式の1次 元 $\mathcal{H}_{\infty}$ コントローラ索用いたときの，2慣性共振系のパラ メー夕変動を考える。2慣性共振系に拈いて電動機慣性 $J_{1}$, 電動機-負荷間バネ定数 $k$, 負荷慣性 $J_{2}$ に50[\%]のハラメ 一夕変動交仮定する。公称值と不確かさの大きさをれぞ $れ J_{1}, k, J_{2}$ 及び $\delta_{1}, \delta_{k}, \delta_{J_{2}}$ 上すると, 不確かさを含む 変動パラメータ $\tilde{J}_{1} ， \tilde{k} ， \tilde{J}_{2}$ はそれぞれ加法的摂動で

$$
\begin{aligned}
\tilde{J}_{1} & =J_{1}+\delta_{J 1} \Delta_{J 1}, & & \left|\Delta_{J 1}\right|<1 \\
\tilde{k} & =k+\delta_{k} \Delta_{k}, & & \left|\Delta_{k}\right|<1 \\
\tilde{J}_{2} & =J_{2}+\delta_{J_{2}} \Delta_{J 2}, & & \left|\Delta_{J 2}\right|<1
\end{aligned}
$$

、は正規化した不確かさであり，反はそれぞれのパラメータ の50[\%]の值である。また, 図 1 より電動機慣性 $J_{1}$, 負荷 慣性 $J_{2}$ は逆数で表現される変動となるため, 安定条件が保 守的にならないようにフィードバック形式で表す ${ }^{(13) 。 ~}$

変動パラメータを陽に含む2慣性負荷系を図 9 に示寸。こ こで考えたすべての不確かさが同時に存在する場合のロバ スト安定性の評価として, 構造化特異值 $\mu$ にる解析法, す

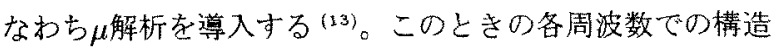
化特異值 $\mu$ ( $\mu$ プロット) 党図10に示寸。同時に, $P I$ 制御及 び共振比制御 (5)により速度制御系を設計したときのパラメ 一夕変動に対する $\mu$ プロットも示す。不確かさが存在しても

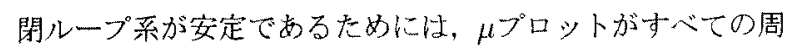
波数で 1 末満でなくてはならない。図10よりPIコントロ 一ラでの $\mu$ ブロットの最大值は 4.2 であり，12[\%](0.5/4.2) のパラメータ変動に対しては制䘖系は口バスト安定でする。 


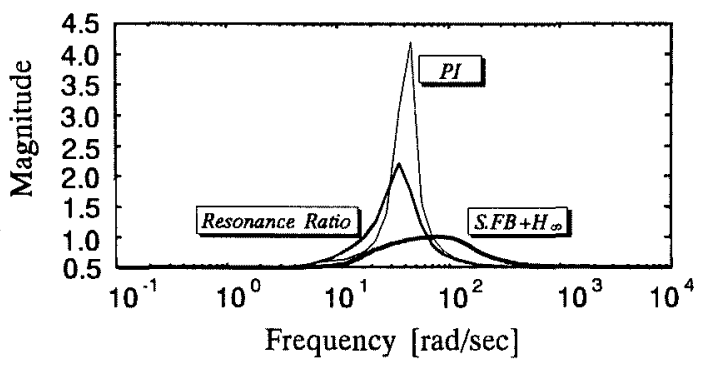

図 $10 \mu$-プロット

Fig. 10. $\mu$ plots of speed control system.

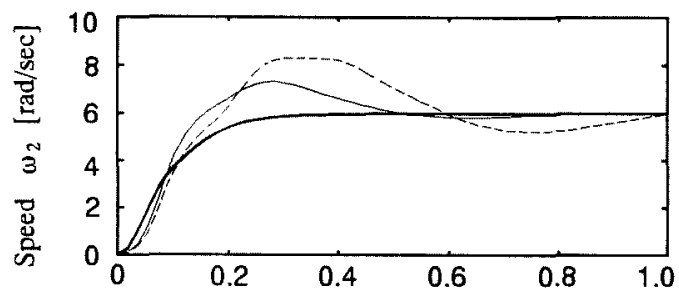

(a) 目標值応答

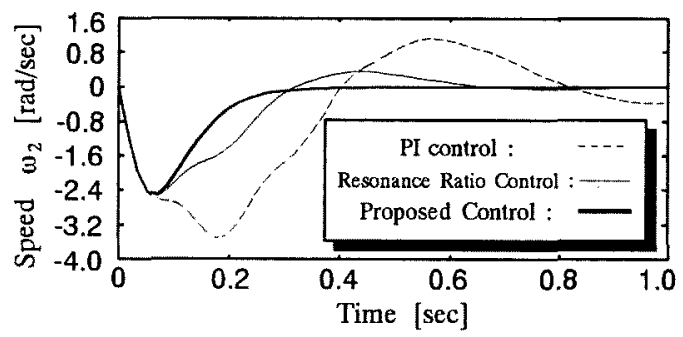

(b)トルク外乱応答

図11 シミュレーションによる目標值応答 及びトルク外乱応答

Fig. 11. Simulation results for speed reference and torque disturbance.

また，共振比制御を用いた場合は，22[\%](0.5/2.3)のパラ メータ変動に対しては制御系は口バス卜安定である。本提 案手法ではその最大值が 1.0 であり，ここで仮定したすべて の不確かさ $(50[\%])$ に対して制御系はロバスト安定さなる。

\section{5. シミュレーション及び実験検証}

〈5.1〉 シミュレーション䊅果 前章で設計した 1 次元 $\mathcal{H}_{\infty}$ コントローラによる2慣性共振系の制振制御について, その有効性をシミュレーションにより示す。速度ステッブ 指令及びトルク外乱に対するシミュレーション結果, 及び 速度制御系のカットオフ周波数 $\omega_{\mathrm{c}}$ を同程度に設定した $P I$ 制御及び共振比制御(5)を用いたときのシミュレーション結 果图 11 に示す。各制御法に比べ，本提案手法注速度指令， トルク外乱どちらに対しても振動することなく，当初の目 的通り良好な特性が得られていることがわかる。

$\langle 5-2\rangle$ 実験䊅果実験装置の構成を図 12 に示す。可 変慣性機構, バックラッシュ機構, 摩擦機構を持ち, 躯動 側及び負荷側共にインバータ駆動のBLDCモータであり，

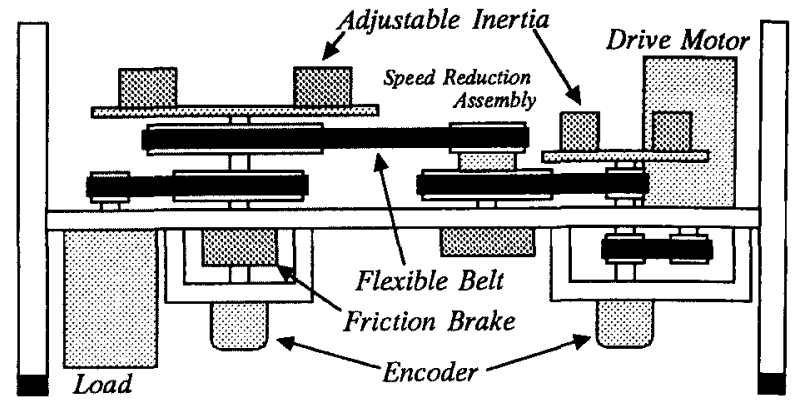

図 122 慣性共振系実験装置の概要図

Fig. 12. Experimental setup for two-mass resonant system.

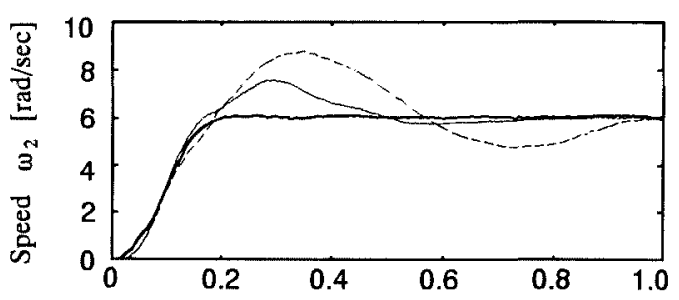

(a) 目標値応答

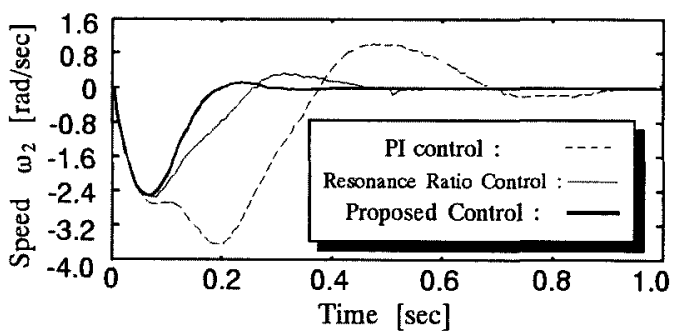

(b)トルク外乱応答

図 13 目標值およびトルク外乱に対する実験結果

Fig. 13. Experimental results for speed reference and torque disturbance.

駆動側には高速応答の電流制御が施されている。また，ギ ア比は 4:1である。本実験では電動機側エンコーダからの 情報のみ在使用し，負荷側エンコーダの情報については実 験検証用にのみ用いた。

エンコーダ出力は各サンプルごそにDSP上に読み込ま れ, 制御演算後 D/A 変換され電流指令として出力される。 各パラメータは表1に示した通りである。

本提案手法，共振比制御及び $P I$ 制御を適用したときの速 度ステップ指令及びトルク外乱に対する実験結果を図 $13 k$ 示す。振動なく良好な応答特性が得られている。

次に, $J_{1}, k, J_{2}$ のパラメータ変動に対する実験を行っ た。その結果, 最も慣性比 $\left(J_{2} / J_{1}\right)$ が小さく, 特性変化の 現れたパラメータ変動

$$
\left(\Delta_{J 1}, \Delta_{k}, \Delta_{J 2}\right)=(1,0,-1)
$$

に対する応答特性を図 14に示す。速度指令に対しては共振 比制御法に比べ著しい特性改善は見られないが，トルク外 乱に対してはその構造上大きな振動抑制効果が得られ，口 

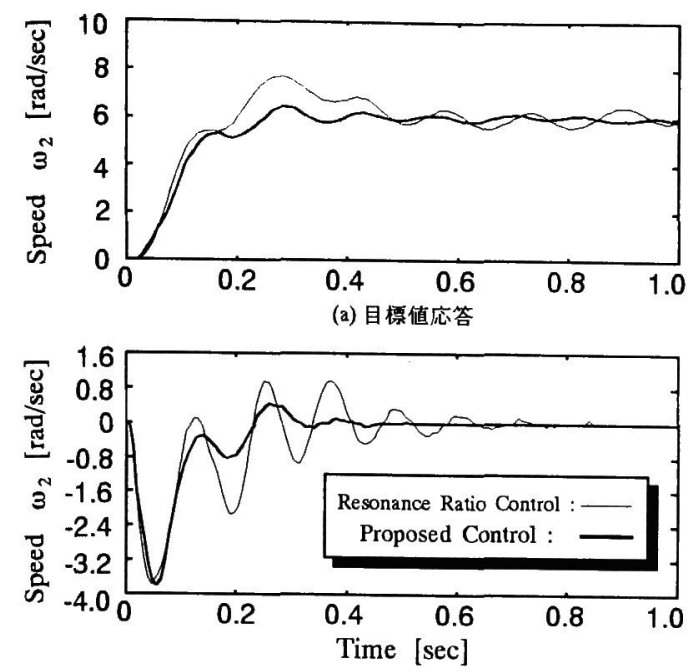

(b) トルク外乱応答

図 14 パラメータ変動に対する実験結果

Fig. 14. Experimental results for parameter variations.

\section{バスト性にも優れていることがわかる。}

\section{6. あとがき}

本論文では，トルク外乱特性改善を主たる目的とした 状態フィードバック補償による制御対象の極配置法, 及び 不確かさを陽に考慮し低次元化した $\mathcal{H}_{\infty}$ コントローラの設 計法を提案し, シミュレーション及び実験によりその有効 性を検証した。まず，極配置法では，トルク外乱に対する 共振特性および定常特性が改善された。同時に制御対象の 共振特性が改善されるため，低次元化したときの乗法的不 確かさの影響を小さくできた。また, 極配置や重み関数の 設定に対する設計指針を明確にできた。

$\mathcal{H}_{\infty}$ コントローラを用いた速度制御系の設計法では，口 バスト安定性を保証した制御対象の低次元化が実装上重要 となる。本提案手法では, ロバスト安定性を保証する低次 の $\mathcal{H}_{\infty}$ コントローラの設計が可能であり，ここでは設計さ れる $\mathcal{H}_{\infty}$ コントローラの次数を一次まで低次元化できた。

尚, 本研究は文部省科学研究費補助金によって行われた ことを付記する。

(平成 9 年 7 月 22 日受付, 同 9 年 11 月 10 日再受付)

文献

（1）松井，堀：「モータコントロールの新しい技術」，電学論 D, Vol 113 , No. 10, pp. 1122-1137 (1993)

（2）結城，村上，大西：「共振比制御による2 瑻性共振系の振動抑制制 御」、電学論 D, Vol. 113, No. 10. pp. 1162-1169 (1993)

（3）久保:「軸初じれ系の新しい制御法: 状態フィードバック」，平成6 年 電気学会産業応用部門全国大会满演論文集. S. 12-5, pp. S.319-322

（4）摆：「2慣性共振系の新しい制御法と最近の動问」，SICEロバスト 制御研究会資料, pp. 1A1-1A6 (1995)

（5）森本, 亀山, 武田:「外乱オブザーバを用いた共振機械采の速度制御シ
ステムとその設計法」, 電学論 C, Vol. 115, No. 11, pp. 1273-1278 (1995)

（6）森. 武市, 駒田, 石田, 嚗:「外乱オブザーバを付加した2慣性共振 系の $\boldsymbol{H}_{\infty}$ 制御法による速度制御」, 電学論 D, Vol. 114, No. 11 , pp. 1173-1174 (1994)

（7）進藤, 森本, 武田 : 「共振比制御と $\mathcal{H}_{\infty}$ 制御による 2 慣性系の速度制 御」, 平成 6 年電気学会全国大会講演論文集, No. 674

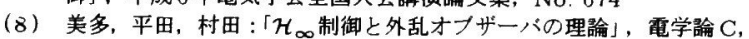
Vol. 115, No. 8, pp. 1002-1011 (1995)

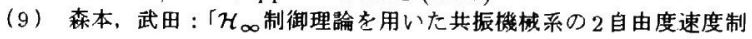
御」, 電学論 D. Vol. 116, No. 1, pp. 65-70 (1996)

(10) 木村, 藤井、菻：「ロバスト制御」、コロナ社 (1994)

(11) J. K. Ji, D. C. Lee and S. K. Sul :" LQG Based Speed Controller for Torsional Vibration Suppression in 2-Mass Motor Drive System", IECON'93, pp. 1157-1162, 1993.

(12) T. Kimura, S. Hara and T. Tomisaka : " $\mathcal{H}_{\infty}$ Control with Minor Feedback for a Pneumatic Actuator System", CDC'96, pp. 2365-2370, 1996.

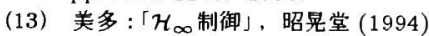

（14）桥本，国分，船渡，神山：「 3 慣性共振系の制振制御に関する一考 察 〜不磪加を陽に考虑した $\mathcal{H}_{\infty}$ 制御〜」, 電気学会金属産業. 産業電力雨気応用合同研究会, IEA-95-14, pp. 69-76 (1995)

（15）灀本, 神山：「2 慣性共振系の速度制御用 $\mathcal{H}_{\infty} コ$ コンローラの次数低 堿化」, 電学論 D研究開発レター, Vol. 115, No. 8, pp. 1070-1071 (1995)

㮇本城司

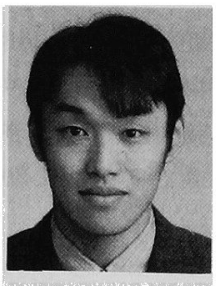

(学生員) 1971 年 12 月 19 日生。1996 年 3 月宇都 宮大学大学院工学研究科電気電子工学専攻博士前 期課程修了。同年 4 月宇都宮大学大学院工学研究 科博士後期課程入学, 現在に至る。ロバスト制御, システム同定のモーションコントロール, 構造体 の制振制御分野人の応用研究に従事。平成 7 年電 気学会論文発表賞受賞。電気学会, 計測自動制御 学会, IEEE 学生会員。

船度 㒻人（正員）電学論 $\mathrm{D}, 117$ 巻 9 号参照。

山本 磨人 (学生員) 1975 年3 月 14 日生。1997年3月宇都宮大

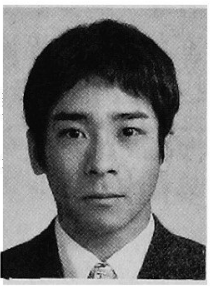
学電気電子工学科卒業。同年 4 月宇都宮大学大学 院工学研究科博士前期課程入学, 現在に至る。シ ステム同定, 適応制御のモーションコントロール 分野八の応用研究に従事。電気学会, 計測自動制 御学会学生会員。

原 志 (学生員) 電学論 D, 117 巻 9 号参照。

神山煡三（正員）1936年 3 月 12 日生。1961 年 3 月早稲田大学

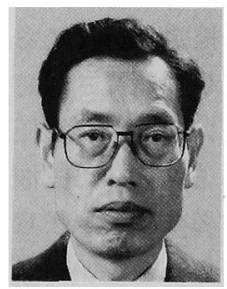
大学院修士課程修了。同年 4 月 (株) 日立製作所入 社, モータドライブの開発設計に従事, 1991 年 3 月退社。1991 年 4 月宇都宮大学工学部教授，現在 に至る。工学博士。パワーエレクトロニクス, モ ータドライブ及びアドバンスト制御の研究と教育 に従事。電気学会, 計測自動制御学会, IEEEな どの会員。 